\title{
Local Government Finance in Pakistan Post 2001
}

\author{
Shahid Kardar ${ }^{*}$
}

\begin{abstract}
The paper calls for financial devolution from the federal and provincial levels to the local level. The author argues that the present high degree of centralization has failed to deliver an adequate level of social services. In addition, while the more important services such as education, health and water supply had devolved to the local level, higher levels of government imposed constraints on their expenditures.
\end{abstract}

\section{Introduction}

Fiscal decentralization and local government finance in Pakistan has to be placed within the context of federalism in general. The reality is that despite being ostensibly a federation, Pakistan has a highly centralized structure, characterized by the constitutional assignment of powers and the political, administration and fiscal systems.

For instance, the Constitution of Pakistan gives the Federal Government the power to levy the most productive taxes under present conditions - taxes on non-agricultural incomes, taxes on imports, production or excise duties and sales taxes. Once collected, these taxes are then shared between the federal government and the provinces and between the provinces and local governments.

The vertical, structural imbalance between the centralization of revenue raising and borrowing powers, and the assignment of relatively greater expenditure responsibilities to lower level governments is part and parcel of the centripetal features of the Pakistani style of federalism, even if we ignore for this purpose the influential role of the military in determining who rules the country and how it is ruled. Given this vertical imbalance, transfers inevitably must play a key role in achieving horizontal equity across provinces and local governments.

\footnotetext{
${ }^{*}$ Managing Partner of Issues \& Policies Consultants
} 
Having contextualized the scope and content of fiscal federalism, let us proceed to discuss the concept and the manner of its application in the case of local governments in Pakistan.

\section{The Theory of Fiscal Decentralization in Pakistan}

Fiscal decentralization is the fiscal empowerment of lower tiers of government, involving the devolution of powers to tax and spend, along with arrangements for correcting the imbalances between resources and obligations. The effectiveness of fiscal decentralization depends upon: (a) appropriate expenditure assignments - with the division of functions among different levels of government depending upon their comparative advantage (called the principle of subsidiarity); (b) appropriate tax or revenue assignments; and (c) the efficient design of a system of transfers and its proper implementation.

Under the Provincial Local Government Ordinances (LGOs) of 2001 (arrangements protected by Schedule VI of the Constitution) which regulate local government systems and provincial-local relationships, administrative and financial authority with respect to the delivery of key social services (e.g. schooling, basic health care, drinking water facilities and municipal functions such as sanitation) has been devolved to lower formations of government (around 110 District Governments, 335 Tehsil Municipal Administrations and 6022 Union Councils). However, there is a mismatch between the responsibilities assigned to them and the financial wherewithal available to them to discharge these obligations (see Table 1 for the rather limited and, at the same time, rather strange powers of local governments to levy taxes, with TMAs having more taxation powers and broader tax bases than district governments).

In terms of GDP, revenues from own sources of local governments is below $0.1 \%$. The buoyancy and potency of the taxes assigned suffers not only on account of a narrow and largely inelastic tax base, the difficulties of making use of the assigned restricted base, and weaknesses in tax administration, but also because of the absence of incentives to raise their own revenues. The tax base is constricted primarily because of (a) as explained above a centralized national tax structure and the almost exclusive powers granted by the Constitution to the Federal Government to make use of the revenue potential provided by all major, broad based, and buoyant taxes; and the (b) the pre-emption by the Federal Government on some taxes that comprise the provincial revenue base. 
Table-1: Revenue-raising Authorities of Local Government

\begin{tabular}{|c|c|c|}
\hline $\begin{array}{c}\text { District } \\
\text { Governments }\end{array}$ & Councils & $\begin{array}{l}\text { Union } \\
\text { Councils }\end{array}$ \\
\hline $\begin{array}{l}\text { Education tax. } \\
\text { - Health tax. } \\
\text { - Tax on vehicles } \\
\text { other than motor } \\
\text { vehicles. } \\
\text { - Local rate on lands } \\
\text { assessable to land } \\
\text { revenue. } \\
\text { - Fees with respect } \\
\text { to schools, colleges, } \\
\text { and health facilities } \\
\text { established or } \\
\text { maintained by the } \\
\text { district } \\
\text { governments. } \\
\text { Fees for licences } \\
\text { granted by the } \\
\text { district } \\
\text { government. } \\
\text { Fees for specific } \\
\text { services rendered } \\
\text { by a district } \\
\text { government. } \\
\text { Collection charges } \\
\text { for recovery of } \\
\text { taxes on behalf of } \\
\text { the government as } \\
\text { prescribed. } \\
\text { - Tolls on new roads, } \\
\text { bridges, within the } \\
\text { limits of a district, } \\
\text { other than national } \\
\text { and provincial } \\
\text { highways and roads. }\end{array}$ & $\begin{array}{l}\text { ax on services. } \\
\text { the transfer of } \\
\text { able property. } \\
\text { ty tax on annual rental } \\
\text { f buildings and lands. } \\
\text { advertisement, other } \\
\text { h radio and television, } \\
\text { lboards. } \\
\text { fairs, agricultural } \\
\text { cattle fairs, industrial } \\
\text { ions, tournaments and } \\
\text { ublic events. } \\
\text { approval of building } \\
\text { nd erection and re- } \\
\text { n of buildings. } \\
\text { licences or permits } \\
\text { nalties or fines for } \\
\text { n of the licensing } \\
\text { for execution and } \\
\text { nance of works of } \\
\text { utility like lighting of } \\
\text { places, drainage, } \\
\text { ancy, and water supply. } \\
\text { cinemas, theatrical } \\
\text { and tickets thereof, } \\
\text { ner entertainment. } \\
\text { ion charges for } \\
\text { y of any tax on behalf } \\
\text { iment, Union } \\
\text { istration or any } \\
\text { ry authority as }\end{array}$ & $\begin{array}{l}\text { - Fees for } \\
\text { licensing of } \\
\text { professions and } \\
\text { vocation. } \\
\text { - Fee on sales of } \\
\text { animals in } \\
\text { cattle markets. } \\
\text { - Market fees. } \\
\text { - Fees for } \\
\text { certification of } \\
\text { births, } \\
\text { marriages and } \\
\text { deaths. } \\
\text { - Charges for } \\
\text { specific services } \\
\text { rendered by the } \\
\text { union council. } \\
\text { - Rate for the } \\
\text { remuneration } \\
\text { of village and } \\
\text { neighbourhood } \\
\text { guards. } \\
\text { - Rate for the } \\
\text { execution or } \\
\text { maintenance of } \\
\text { any work of } \\
\text { public utility } \\
\text { like lighting of } \\
\text { public places, } \\
\text { drainage, } \\
\text { conservancy } \\
\text { and water } \\
\text { supply. } \\
\text { and }\end{array}$ \\
\hline
\end{tabular}

On grounds of equity, efficiency and economy, powers to levy and collect taxes on imports, incomes, and sales tax on the principles of GST (or VAT) in a federal system need to be centralized in the Federal Government 
(since decentralized administration of customs related duties, sales tax and excise duties, while feasible, would impede the free flow of goods and services) while expenditure responsibilities are assigned to sub-national governments. This limited decentralization of powers to the lower tiers of government to levy and collect taxes with substantial decentralization of spending obligations results in a vertical imbalance. This mismatch between taxation powers and expenditure responsibilities has to be addressed through resource transfers from the higher levels of government to the lower levels.

To address these imbalances in the case of local governments, the LGOs provide for an assessment of their needs through the Provincial Finance Commissions (PFCs). Under the governing legislation, the PFCs are entrusted with the task of reviewing and examining the existing economic situation and the changes taking place and announcing a three-year transparent, formula based Award for transferring resources to local governments.

A review of some indicators of fiscal decentralization reveals that Pakistan's vertical imbalances are much more pronounced in comparison with international standards. Moreover, district governments are much more heavily dependent on provincial transfers than TMAs which have a relatively broader base of own revenues. ${ }^{1}$

Table-2: Fiscal Decentralization in Major Developing Country Federations

\begin{tabular}{lcccc}
\hline $\begin{array}{c}\text { Federation } \\
\text { Developing } \\
\text { Country }\end{array}$ & $\begin{array}{c}\text { Sub-National } \\
\text { Expenditures } \\
\text { (\% Total) }\end{array}$ & $\begin{array}{c}\text { Sub-National } \\
\text { Expenditures } \\
\text { (\% GDP) }\end{array}$ & $\begin{array}{c}\text { Sub-National Own } \\
\text { Revenues (\% Total } \\
\text { National Revenues) }\end{array}$ & $\begin{array}{c}\text { Sub-National } \\
\text { Own Revenues } \\
\text { (\% GDP) }\end{array}$ \\
\hline Pakistan & (I) & (II) & (III) & (IV) \\
India & 34.2 & 6.3 & 7.0 & 0.9 \\
Nigeria & 39.2 & 10.8 & 33.8 & 6.1 \\
South Africa & 56.5 & 13.6 & 10.7 & 3.2 \\
Argentina & 44.4 & 18.9 & 18.9 & 6.1 \\
Brazil & 41.7 & 12.4 & 44.2 & 8.4 \\
Mexico & 41.0 & 7.4 & 39.0 & 10.5 \\
Malaysia & 11.0 & 2.4 & 25.5 & 4.5 \\
\hline
\end{tabular}

Source: Kai Kaiser, 2006 and Budget of Federal Government FY 2005/06.

\footnotetext{
${ }^{1}$ TMAs are entitled to receive (a) $2.5 \%$ of GST in lieu of withdrawn octroi and zilla tax;
} and (b) property tax collected from their jurisdiction. 
Table-3: Proportions of Total Funding Transferred to Local Governments on a Formula-basis [Rupees in million (R.E. 2002/03)]

\begin{tabular}{lc}
\hline \multicolumn{1}{c}{ Province } & Formula based transfers \\
\cline { 2 - 2 } & \% of Provincial Consolidated Fund \\
\hline Balochistan & 3.76 \\
NWFP & 3.53 \\
Punjab & 4.66 \\
Sindh & 7.82 \\
\hline
\end{tabular}

Source: Kai Kaiser, January 2006.

While in India transfers as a percentage of state expenditure is 7\%, in Pakistan it hardly touches $4 \%$. However, in contrast to other federations, Pakistan relies more on the divisible pool and straight transfers instead of conditional/tied grants. As a result, at the level of spending, autonomy is theoretically high. Moreover, the advantage of tax devolution on the basis of a formula is that it not only provides for a predictable source of revenue for local governments, it also enables them to benefit automatically from an increase in the size of the divisible pool. Another advantage of such a principle of distribution is that of certainty, so that conflict and continuous bargaining can be avoided.

However, the total expenditure of local governments as a proportion of the combined expenditure of the Federal, provincial, and local governments is less than $1 \%$ compared with $4 \%$ in India and 20 to $35 \%$ in advanced countries $(45 \%$ in Denmark $)$, despite the Constitutional amendment intended to transfer power, authority, and resources to local government. Local government expenditure as a percent of provincial and local government expenditure is less than $4 \%$ compared with $9.5 \%$ in India.

\section{The Practice of Fiscal Decentralization}

Anecdotal evidence and discussions with local government representatives suggest that local governments do not have adequate capacity, both human and financial, to satisfy their mandates. ${ }^{2}$ The responsibilities for delivering basic social services were devolved without adequate resources in terms of matching mandates and financial wherewithal through administrative

${ }^{2}$ Partly with the help of donors, the provincial governments have been helping district governments establish systems of local government accounting and finance and building up the technical capability of district governments to perform the functions mandated to them under related legislation. 
and fiscal decentralization to lower formations of government, even though as indicated above, the financial resource flows are largely predictable.

Using population and a backwardness index, districts were ranked on health, education, housing, employment and residential services indicators in three provinces and by the tax effort in Sindh. In NWFP, the backwardness index has been developed from a recent Multiple Indicator Cluster Survey [MICS] (which includes health, education, literacy, income and access to safe drinking water) while $25 \%$ is based on infrastructure deficiency.

Table-4: Weights used in horizontal distribution in the Provincial Finance Awards

\begin{tabular}{lcccc}
\hline \multicolumn{1}{c}{ Weightings } & Punjab & Sindh & NWFP & Balochistan \\
\hline Population & $67 \%$ & $50 \%$ & $50 \%$ & $50 \%$ \\
Backwardness & $33 \%^{3}$ & $17.5 \%^{4}$ & $25 \%^{5}$ & \\
Tax effort/collection & & $7.5 \%^{6}$ & & \\
Performance & & $5 \%$ & & \\
Area & & & $50 \%$ \\
Development incentive/ & & $25 \%$ & \\
infrastructure deficiency & & & \\
Transitional assistance (grants) & & $20 \%$ & & \\
\hline
\end{tabular}

Source: Devolution in Pakistan, Asian Development Bank, Department for International Development, World Bank, 3 Volume Draft, March 16, 2004 and updates based on discussions with the Governments of Punjab and Sindh.

\footnotetext{
${ }^{3}$ Both of these indices have been developed from the PERI "development score" index. The "development score" was taken from the Punjab Economic Research Institute (PERI) study of district-wise development scores in various economic sectors.

4 The "Backwardness Index" is the "Deprivation Index" developed by the Social Policy and Development Centre (SPDC).

5 The "backwardness" index is derived from the UNICEF sponsored Multi-Indicator Cluster Survey (MICS), which includes: child survival and nutrition; immunization and EPI for children up to 5 years of age; education and literacy; availability of drinking water; and income.

6 The "tax collection" index is based on provincial tax revenues collected in different districts in 1999/00. The index was estimated as a percentage of provincial tax revenue collected in each district (in FY01). It shows the government's attempt to plow back some of the tax revenue into the district and indicates only the tax capacity and not the tax effort of the district.
} 
In the absence of credible and comparable data for designing an appropriate PFC distribution formula and unit costs for delivering key social services in different parts of the province (factoring in a minimum standard of public service), transfers to local governments in the Punjab were made in accordance with historical shares, which were not formula driven but determined by allocations made in the past (largely to meet existing establishment costs of staff located in these districts) or by historical collections of octroi and zilla tax (in the case of TMAs). This baseline of expenditures was treated as an indicator of need, to ensure uninterrupted delivery of social services.

However, to finance the development programs of local governments districts were ranked on the basis of generally accepted indicators of development and a formula was devised to give greater weightage in per capita allocations to the more backward districts. In other words, there were some limited transparent formula-based allocations to finance development programs. In the Punjab, the allocation for the municipalities, the Tehsi1/ Town Municipal Administrations (TMAs), is based purely on population, while Union Councils have been allocated Rs. 60,000 each per month (Rs.180,000 per council in Lahore).

Sindh was the first province to design a formula for the sharing of the "allocatable fund" among districts. However, the weakness in its PFC Award is that it has two separate, although similar formulas, for the sharing of the resources to finance recurrent and development spending. The shares of recurrent resources are further split into salary and nonsalary components limiting the autonomy of the district governments to develop their own budgets. Moreover, only the non-salary budget is being released to Account Number IV controlled solely by the district government. The salary and development components are being transferred through the provincial Account Number 1, undermining the autonomy of the district governments to formulate their own development strategies and rationalize their staffing strength in terms of numbers, skill, and salaries of personnel.

Furthermore, in the case of Sindh and NWFP, autonomy in preparing salary budgets is also limited because the divisible pool transfers for meeting establishment costs (a major proportion of their spending) are restricted to the expenditure on actual salaries, and not on the basis of sanctioned posts. With district governments not being allowed to alter their workforce, all savings from unfilled staff positions accrue exclusively to the provincial government. Not surprisingly, district governments encountered financial difficulties when vacant sanctioned posts were filled. 
To date, allocations to district governments by the provincial governments have been barely enough to meet salary obligations, let alone the expanded expenditure requirements of non-salary inputs, funding to finance O\&M activities, key missing infrastructure, and sustainable improvements in the service delivery system. For instance, in Balochistan the budgetary allocations for the operations and maintenance of water supply schemes have not been devolved and continue to be reflected in the budget of the PHED at the provincial level, although the management of the schemes has been transferred to the TMAs. Poor incentives for service delivery, weak governance systems, and highly centralized systems of public spending exacerbate the issues identified above. ${ }^{7}$

Since a large part of the budget lies beyond their control, district governments hardly have any autonomy for re-allocating resources based on their own priorities. While there are no statutory limitations, notifications, instructions, and guidelines are employed to influence the budget making process. For example (a) the NWFP has prescribed targets for apportioning development funds between sectors; (b) the Punjab has notified a minimum proportion for repairs and maintenance; (c) Sindh disburses development funds based on implementation; and (d) in Balochistan funds have also been set aside from the MPA schemes and withheld from district governments. However, despite these restrictions the ownership of budgets and the budget making process has improved.

Moreover, there are a large number of Federal and Provincial Government run vertical programs ${ }^{8}$ that influence local policy and budgets through their implications for recurrent expenditures as well as the capacity of local governments to plan, design, and implement projects reflecting local priorities. Such programs not only undermine accountability but also impinge upon the flexibility and room for the maneuverability of local governments.

Even in matters relating to taxes assigned to local governments (such as to the TMAs) their capacity as well as the incentive to expand the property tax base and rationalize collections and distribution arrangements is severely affected by the decision of the provincial governments to retain authority on policies pertaining to exemptions, rating areas, tax rates, and methodologies to assess property values.

\footnotetext{
${ }^{7}$ There is lack of clarity on responsibilities (in fact there is an overlap) of PHEDs and TMAs.

${ }^{8}$ According to a 3-volume study conducted jointly by ADB, DfID and World Bank, "Devolution in Pakistan", vertical programs were more than $50 \%$ of the ADPs of 4 districts studied by the team (and as much as $91 \%$ in the case of Faisalabad).
} 
Finally, provincial governments are not only reluctant to hand over some of their already narrow revenue bases to the local governments but also to grant greater spending autonomy when confronted with the lack of their own revenue bases and uncertainty of adequate resource flows. Their unwillingness stems particularly from the future demands on divisible pool transfers to meet the salary bill of existing and additional staff and payments pertaining to retirement benefits.

\section{Recommendations}

The PFC Awards need to (a) provide more resources to local governments if the country is to achieve its Millennium Development Goals; and (b) design more equitable arrangements for the distribution of resources between the province and the districts and among districts to enable each level of government to fulfill its constitutional responsibilities in an efficient and effective manner. For this, fiscal equalization transfers would be required to ensure minimum standards of social services while making governments accountable for the quality of these services.

There is also a need to develop mechanisms and instruments for incentive and conditional grants (based on revenue performance or to implement provincial priorities - say with respect to the social sectors consistent with national poverty reduction objectives) and revise them periodically to reflect the implementation experience. While conditional grants tend to undermine the responsiveness and accountability of local representatives to their constituents, they still have the potential to serve as instruments through which the provincial government can retain an interest in reforms and service delivery mechanisms in addition to institutional and process arrangements at the lower levels.

In my view, a system of conditional grants could be proposed for the next 3 years or so, until district governments acquire a certain degree of maturity, good governance structures and practices are fortified and these governments become better equipped to determine local priorities and develop capacity to fulfill their mandates by utilizing scarce human and financial resources more efficiently and effectively. The effectiveness of implementation of provincial funded programmes aimed at improving access to education and enhancing participation and retention rates can be evaluated against generally accepted outcomes and performance indicators, such as enrolment levels, participation rates, etc. However, as provided for in the LGOs, district governments should continue to have greater flexibility over the use of funds to satisfy local needs from flows assured under the 
PFC Award, so as not to limit or compromise their operational autonomy guaranteed by the legislation.

The most rational horizontal distribution would give adequate weightage to equity and efficiency - population as a dominant criterion followed by area (since there is a minimum unit cost for producing a certain standard of service), tax effort, and some indicators of backwardness.

There is a need to develop mechanisms for (a) encouraging local revenue generation (by completely devolving the Agricultural Income Tax (AIT) to district governments and Property Tax to TMAs, the vertical gap can be reduced); (b) instituting policy or conditional grants for local action on provincial priorities; and (c) better sharing of development expenditures in devolved sectors with local governments.

Local governments should also be allowed to impose user charges for non-merit goods and services and retain the collections without an accompanying adjustment in the divisible pool transfers for those governments levying them.

There is also a need to consider provisions of grants and awards for local governments performing well (a) based on the results of surveys like MICS or a Citizen Report Card; and/or (b) linked to agreed outputs/outcomes.

Finally, there is a need to protect local governments from the negative impact of the fiscal imprudence of a provincial government.

Permanent PFC Secretariats also need to be established in the Provincial Departments of Finance (FDs) [also required by the LGOs] which will have access to an up-to-date comprehensive and reliable database of macro-economic trends in the province, district level demographics, key development indicators, revenue receipts and other transfers, budgetary allocations, and actual expenditures, etc. Such a database will enable the provincial FDs to track expenditures, ensure Award implementation and based on actual experience, derive lessons for incorporation in future Awards, especially to make transfers purely formula driven with a gradual phasing out of the current practice to provide funds based on historical flows.

\section{Other Issues with Decentralization}

Provincial governments view the devolution framework as an instrument undermining their authority, with little dilution of Federal authority. Until the recent elections there were some district governments 
with different political party alignments from those of the provincial governments. This created operational problems for local governments making devolution quite controversial.

The adoption of the provincial government's business processes and systems has made the achievement of the envisaged objectives difficult. One of the key stated objectives of the devolution framework was to devolve power such that those residing in say Pakpattan, Punjab, would not have to come to Lahore (the provincial capital) to get their grievances redressed. The underlying model was conceptually flawed in that it assumed that those residing in Lahore had no such complaints and could access government to get such matters attended to. Resultantly, there have been marginal improvements in service delivery since the final product (the district governments) of the respective LGOs now resembles 34 mini provincial governments in the Punjab.

Another conceptual flaw was the assumption that since governments had done a poor job in handling the economic sectors and carrying out commercial and business activity they should be focusing their energies and resources on managing the social sectors, with little evidence that governments, both provincial and Federal, in Pakistan had performed any better in administering these sectors. For example in education, there is ample data that even less affluent households are voting with their feet and opting for private schools for their children (Kardar, 1996/97).

However, a major achievement has been the acceptance, albeit reluctant, for devolution as a fact of life with a complete return to earlier institutional arrangements unlikely in view of the failure of old structures to deliver social services efficiently and effectively. The creation of institutional structures, rules for the formation of government, opportunities for citizen groups to participate in decision making and in the planning, design, and implementation of development schemes, some degree of predictability in resource transfers in the form of the pre-determined shares and greater autonomy on allocations for non-salary items and the non-lapsing nature of the transferred amount, has enabled local government structures, arrangements, and systems to acquire a certain degree of permanence.

\section{Conclusion}

In Pakistan, local governments are important not only because of their significance in the context of devolution providing public services but also because of the failure of the Federal and Provincial Governments to provide quality services since the birth of the country. 
This paper has tried to demonstrate that despite the Sixth Constitutional Amendment and associated legislation having been key landmarks in empowering local governments, the assignment of powers to local governments in actual practice has been limited. The main challenge is the overlapping jurisdictions in practice between provincial governments and local governments, with the former wanting the latter to function mainly as their decentralized agents, as in the past.

The existing distribution formulae governing inter-governmental fiscal transfers are not norm-based, since only a small proportion of the transfers are formula based; less than $8 \%$ of the Provincial Consolidated Fund ultimately transferred is on the basis of formulae.

The Awards, announced so far (except in the case of Sindh) on the basis of spending needs only, ignoring the fiscal capacities of different local governments, are inequitable. They have not seemingly recognized the role of fiscal transfers in improving efficiency and equity by creating the appropriate incentives for a responsive and accountable system of governance.

Moreover, local governments do not have autonomy to determine priorities or change the composition of expenditures. Their autonomy to prepare their own recurrent and development budgets is restricted by provincial policies, the impacts of federal and provincial vertical programs (through their implications on future recurrent budgets), and the throwforward of ongoing development schemes that they have inherited.

The jury is still out on the efficiency and effectiveness of these institutions and their continuation in this form in the future. One school of thought, to which this author also belongs, argues that since provincial governments view their authority being weakened, the structure and scope of devolution is likely to change with the exit of Pervez Musharraf from the political scene, whenever it takes place. The lasting structures likely to emerge from this debris will be a hybrid of the new and the old. 


\section{References}

Asian Development Bank, Department for International Development, World Bank, Devolution in Pakistan, 3 Volume Draft, March 16, 2004.

Fukasaku Kichiro and L.R. DeMello Jr., 1999, Fiscal Decentralization in Emerging Economies, OECD, Paris.

Kai Kaiser, January 2006, Inter-governmental Fiscal Relations in Pakistan: Structural challenges for the 2001 Devolution, Draft Background Note for National Tax Association Meeting.

Kardar, Shahid, Demand for Education, Two Studies Involving Surveys of 1,000 Households in Karachi and 1,500 households in 5 Districts of the Punjab, 1996 and 1997.

Oommen, M.A., 2004, Fiscal Decentralization in Kerala in Geeta Sethi (ed.), Fiscal Decentralization to Rural Governments in India, Oxford University Press. 
